\title{
Prostate cancer as a first and second cancer: effect of family history
}

\author{
H Zhang', JL Bermejo', ${ }^{1,2}$ J Sundquist ${ }^{3}$ and K Hemminki*, 1,4 \\ 'Division of Molecular Genetic Epidemiology, German Cancer Research Center (DKFZ), Heidelberg 69120, Germany; ${ }^{2}$ Institute of Medical Biometry and \\ Informatics, University Hospital Heidelberg, Heidelberg 69120, Germany; ${ }^{3}$ Center for Primary Health Care Research, Lund University, Malmö 20502, \\ Sweden; ${ }^{4}$ Center for Family and Community Medicine, Karolinska Institute, Alfred Nobels alle 12, Huddinge 14183, Sweden
}

BACKGROUND: Diagnosis with prostate cancer has been reported to increase the risk of subsequent tumours. However, specific data on individuals with a parental history are not available so far.

METHODS: On the basis of the nationwide Swedish Family-Cancer Database including 18,207 primary invasive prostate cancers, standardised incidence ratios (SIRs) were used to estimate the relative risks of subsequent tumours after prostate cancer in the general population and among individuals with a parental history of cancer.

RESULTS: A significantly increased SIR of colorectal cancer was found among prostate cancer patients with a parental history of colorectal cancer $(2.26,1$ I cases). The SIRs of parental concordant (same site) tumours after prostate cancer were also increased for urinary bladder cancer (4.42, 4 cases) and chronic lymphoid leukaemia (38.0, 2 cases).

CONCLUSION: A higher than additive and multiplicative interaction was observed between the individual history of prostate cancer and parental history of colorectal and urinary bladder cancers, although the number of cases did not permit the rejection of any interaction model. The results suggest that the occurrence of second tumours, for example bladder after prostate or prostate after bladder tumours, is mostly related to shared genetic and non-genetic risk factors rather than treatment of first cancer. British Journal of Cancer (2009) I 0 I, 935-939. doi:I0.1038/sj.bjc.6605263 www.bjcancer.com

Published online 18 August 2009

(c) 2009 Cancer Research UK

Keywords: familial risk; prostate cancer; second primary malignancy

Prostate cancer is the most common cancer among males in Sweden, with an incidence rate up to 214 per 100000 person-years (Centre for Epidemiology, 2006). The incidence of prostate cancer in Sweden has experienced an annual increase of $3.7 \%$ during the last decade. With the improvement in survival from prostate cancer, more and more survivors might face the problem of having an increased risk for subsequent primary tumours (Travis, 2006; Travis et al, 2006). An increased risk of subsequent prostate cancer after other types of cancer has been also observed (Dong and Hemminki, 2001; Diener-West et al, 2005; Sørensen et al, 2005; Neuzillet et al, 2007). For example, the within-patient clustering of bladder and prostate tumours has been extensively explored (Chun, 1997; Kouriefs et al, 2005; Liauw et al, 2006; Bostrom and Soloway, 2007; Kellen et al, 2007; Bostrom et al, 2008; Singh et al, 2008). The plausible aetiology of multiple subsequent tumours could be the effect of therapy, genetic and non-genetic risk factors, or the interactions between them (Hemminki and Boffetta, 2004; Travis, 2006; Travis et al, 2006). Aetiological studies have mostly focused on therapy-related factors, particular radiotherapy (Brenner, 2006; Kendal et al, 2006; Subramanian et al, 2007; Bostrom and Soloway, 2007). However, radiotherapy does not completely explain the increased risk of second tumours and limited information is available on the potential effect of family history

* Correspondence: Professor K Hemminki, Division of Molecular Genetic Epidemiology, German Cancer Research Center (DKFZ), Heidelberg 69120, Germany; E-mail: k.hemminki@dkfz.de

Received II May 2009; revised 9 July 2009; accepted 23 July 2009; published online 18 August 2009 on the risk of subsequent tumours after prostate cancer (Singh et al, 2008).

This study investigates the role of parental history in the development of second malignancies after prostate cancer, and the risk of subsequent prostate cancer in familial cases using the 2006 update of the nationwide Swedish Family-Cancer Database. Although cancer is mainly induced by environmental factors and only a small proportion can be explained by established genes, population-based estimation of parental risks is still a good measure of the familial clustering of tumours and reflects the sum of genetic risk effects attributable to both known and unknown genes.

\section{MATERIALS AND METHODS}

The nationwide Swedish Family-Cancer Database includes offspring born in Sweden since 1932 and also their biological parents, with information about the first and second primary malignancies they experienced. Cancer was recorded according to the 7th version of the ICD code (ICD-7), and verified by the cytological or histological code. The agreement between clinical and cytological or histological diagnosis is close to $100 \%$ (Centre for Epidemiology, 2006). Unfortunately, information about cancer treatment is not included in the Swedish Cancer Registry.

Parental risks were investigated when fathers were affected by prostate tumour and when parents were affected by concordant (same site) cancer. On the basis of the Swedish Family-Cancer Database, the relative risk of second tumours in the general population and among individuals with a family history was 
estimated by standardised incidence ratios (SIRs), calculated as the ratio of the observed $(O)$ to expected $(E)$ number of cases. The follow-up started at diagnosis of prostate cancer and ended at the occurrence of death, emigration, the diagnosis of any subsequent malignancy or on 31 December 2004 (end of the study). Cases and person-years were classified according to the categories age (5-year groups), region (4 regions), calendar period (9 intervals) and socioeconomic status (6 groups). Confidence intervals (95\% CI) were calculated assuming a Poisson distribution of the observed number of cases. To evaluate the risk of a second prostate cancer after any cancer, follow-up began at the date of diagnosis of the first malignancy and the uncensored event was the diagnosis of prostate cancer. Multiplicative interaction indexes (MIIs) and interaction contrast ratios (ICRs) were used to investigate the possible interaction between 'individual history of prostate' and 'parental history of cancer'. If SIR $_{\text {prostate }}$ represents the relative risk of cancer after prostate cancer, $S_{\text {IR }}$ represents the relative risk among individuals with a parental history and $\mathrm{SIR}_{\text {prostatexfh }}$ represents the relative risk in prostate cancer patients with a parental history, $\mathrm{MII}=\mathrm{SIR}_{\text {prostatexfh }} /\left(\mathrm{SIR}_{\text {prostate }} \times \mathrm{SIR}_{\mathrm{fh}}\right)$ and $\mathrm{ICR}=\mathrm{SIR}_{\text {prostatexfh }}-\mathrm{SIR}_{\text {prostate }}-\mathrm{SIR}_{\mathrm{fh}}+1 . \quad \mathrm{MII} \neq 1 \quad$ indicates a departure from multiplicativity and $I C R \neq 0$ suggests a departure from additivity. Confidence intervals and $P$-values for MII and ICR were calculated by bootstrapping based on 100000 replications. All analyses were carried out in SAS 9.1, the SAS Institute, Cary, NC, USA.

\section{RESULTS}

A total of 3818429 male offspring were registered and 18207 men were diagnosed with prostate cancer from 1978 to 2004 in Sweden. Among them, 560 experienced a second malignancy after diagnosis; 75269 men were diagnosed with any tumour other than prostate cancer and 838 of them had a subsequent prostate cancer.

The relative risk of cancer after prostate cancer is shown in Table 1 for sites with at least 11 observed subsequent cases (the same sites are shown in Table 2). Compared with the general Swedish population, prostate cancer patients showed an increased risk of cancer in the kidney (SIR: 1.75), urinary bladder (1.83) and skin (squamous cell, 1.67). The increased risk of colorectal cancer (1.23) showed borderline significance. Among patients with a parental history of prostate cancer, the risk was increased for bladder (2.44) and skin squamous cell cancers (3.34) and for myeloma (3.85). The third column of Table 1 shows the relative risks of second cancer in prostate cancer patients with a parental family history of concordant (same site) cancer. Prostate cancer patients with a parental history of colorectal cancer showed a 2.23 times higher risk of colorectal cancer than did men in the general population. Increased familial risks were also observed for urinary bladder (SIR: 4.42) and chronic lymphoid leukaemia (38.0, 2 familial cases affected after prostate cancer). As a control, the parental risk of these cancers as first primary was also shown in the fourth column.

Table 2 provides the risk of prostate cancer as second tumour. Increased risks were detected for kidney (1.56) and urinary bladder (2.25) cancer and for melanoma (1.22). In patients with a paternal history of prostate cancer, a significantly increased risk was observed for colorectal (1.88), renal (3.92) and urinary bladder (3.97) cancers. Among patients with a family history of concordant cancer, only by urinary bladder cancer showed a significantly increased risk after prostate cancer. It is important to point out here that urinary bladder cancer always showed a positive association with prostate cancer, both as first and as second primary tumour, both in the general population and among individuals with a family history.

Table 3 explores the interaction between the individual history of prostate cancer and family history of concordant cancer. For colorectal, urinary bladder and skin cancers, the interaction seemed to be higher than additive and higher than multiplicative. By contrast, a lower than additive and lower than multiplicative interaction was found for kidney cancer. However, the number of cases was small and it did not permit the rejection of any interaction model at the $5 \%$ confidence level.

\section{DISCUSSION}

This study focused on the effect of parental history of cancer on the development of subsequent tumours after prostate cancer, and on the risk of prostate cancer in cancer patients.

The Swedish Family-Cancer Database relies on national registries of complete coverage, thus minimising biases due to recall and ascertainment (Hemminki et al, 2001, 2006). Parents are

Table I Relative risks of second cancer after prostate tumours and familial risks of first primary cancer

\begin{tabular}{|c|c|c|c|c|c|c|c|c|c|c|c|c|c|c|c|c|}
\hline \multirow{4}{*}{$\frac{\text { Type of second cancer }}{\text { Upper aerodigestive tract }}$} & \multicolumn{12}{|c|}{ Risk of second cancer after prostate cancer } & & & & \\
\hline & \multicolumn{4}{|c|}{ Male offspring } & \multicolumn{4}{|c|}{$\begin{array}{l}\text { Sons of men with } \\
\text { prostate cancer }\end{array}$} & \multicolumn{4}{|c|}{$\begin{array}{l}\text { Sons of patients affected by } \\
\text { concordant cancer }\end{array}$} & \multicolumn{4}{|c|}{$\begin{array}{l}\text { Familial risk of first primary } \\
\text { concordant cancer }\end{array}$} \\
\hline & \multirow{2}{*}{$\frac{N}{12}$} & \multirow{2}{*}{$\begin{array}{c}\text { SIR } \\
0.88\end{array}$} & \multicolumn{2}{|c|}{$(95 \% \mathrm{Cl})$} & \multirow{2}{*}{$\begin{array}{l}\mathbf{N} \\
2\end{array}$} & \multirow{2}{*}{$\begin{array}{l}\text { SIR } \\
0.96\end{array}$} & \multicolumn{2}{|c|}{$(95 \% \mathrm{Cl})$} & \multirow{2}{*}{$\frac{N}{1}$} & \multirow{2}{*}{$\begin{array}{c}\text { SIR } \\
10.16\end{array}$} & \multicolumn{2}{|c|}{$(95 \% \mathrm{Cl})$} & \multirow{2}{*}{$\begin{array}{l}\mathbf{N} \\
49\end{array}$} & \multirow{2}{*}{$\begin{array}{l}\text { SIR } \\
1.67\end{array}$} & \multicolumn{2}{|c|}{$(95 \% \mathrm{Cl})$} \\
\hline & & & 0.45 & 1.54 & & & 0.09 & 3.54 & & & 0.00 & 58.2 & & & 1.26 & 2.22 \\
\hline Stomach & 18 & 1.23 & 0.73 & 1.95 & । & 0.47 & 0.00 & 2.70 & 0 & & & & $13 \mid$ & 1.67 & 1.40 & 1.99 \\
\hline Colorectum & 92 & 1.23 & 0.99 & $\mid .51$ & 6 & 0.54 & 0.20 & 1.19 & 11 & 2.26 & 1.12 & 4.06 & 1573 & 1.69 & 1.61 & 1.78 \\
\hline Pancreas & 17 & 1.24 & 0.72 & 1.99 & । & 0.49 & 0.00 & 2.82 & 0 & & & & 85 & 2.01 & 1.62 & 2.50 \\
\hline Lung & 63 & 1.15 & 0.88 & 1.47 & 6 & 0.74 & 0.27 & 1.63 & 2 & 1.15 & 0.11 & 4.21 & 647 & 1.72 & 1.58 & 1.86 \\
\hline Prostate & 18 & 0.05 & 0.03 & 0.09 & 4 & 0.08 & 0.02 & 0.22 & 4 & 0.08 & 0.02 & 0.22 & 2472 & 1.88 & 1.80 & 1.96 \\
\hline Kidney & 33 & 1.75 & 1.20 & 2.46 & 2 & 0.71 & 0.07 & 2.61 & 1 & 2.72 & 0.00 & 15.6 & 119 & 2.19 & 1.82 & 2.62 \\
\hline Urinary bladder & 76 & 1.83 & 1.44 & 2.30 & 15 & 2.44 & 1.36 & 4.03 & 4 & 4.42 & 1.15 & 11.4 & 279 & 1.79 & 1.58 & 2.01 \\
\hline Melanoma & 24 & 0.93 & 0.59 & 1.38 & 5 & 1.22 & 0.39 & 2.87 & 0 & & & & 438 & 2.44 & 2.22 & 2.68 \\
\hline Skin, squamous cell & 37 & 1.67 & 1.18 & 2.31 & 11 & 3.34 & 1.66 & 6.00 & 2 & 4.42 & 0.42 & 16.3 & 172 & 2.03 & 1.74 & 2.36 \\
\hline Nervous system & 25 & 1.47 & 0.95 & 2.17 & 3 & 1.14 & 0.22 & 3.39 & 0 & & & & 257 & 1.69 & 1.50 & 1.92 \\
\hline Non-Hodgkin's lymphoma & 33 & 1.44 & 0.99 & 2.03 & 2 & 0.58 & 0.05 & 2.13 & 1 & 3.24 & 0.00 & 18.6 & 167 & 1.86 & 1.60 & 2.17 \\
\hline Myeloma & 14 & 1.61 & 0.88 & 2.71 & 5 & 3.85 & 1.22 & 9.06 & 1 & 11.7 & 0.00 & 67.0 & 35 & 2.43 & 1.74 & 3.40 \\
\hline Leukaemia & 16 & 0.88 & 0.50 & 1.44 & 3 & I.II & 0.21 & 3.28 & 2 & 6.80 & 0.64 & 25.0 & 150 & 1.87 & 1.58 & 2.19 \\
\hline Chronic lymphoid leukaemia & 8 & 0.97 & 0.43 & 1.93 & 3 & 2.46 & 0.46 & 7.29 & 2 & 38.0 & 3.58 & 140 & 46 & 6.11 & 4.47 & 8.15 \\
\hline Any type & 560 & 0.72 & 0.66 & 0.78 & 79 & 0.69 & 0.54 & 0.86 & 305 & 0.80 & 0.69 & 0.87 & 81548 & 1.05 & 1.05 & 1.06 \\
\hline
\end{tabular}

Abbreviations: $\mathrm{Cl}=$ confidence interval; $\mathrm{N}=$ number of individuals with second neoplasm; SIR = standardised incidence ratio. Bold refers to a significant risk increase with $5 \%$ statistical significance. 
Table 2 Relative risks of prostate tumours as second cancer in the general population and among individuals with a family history

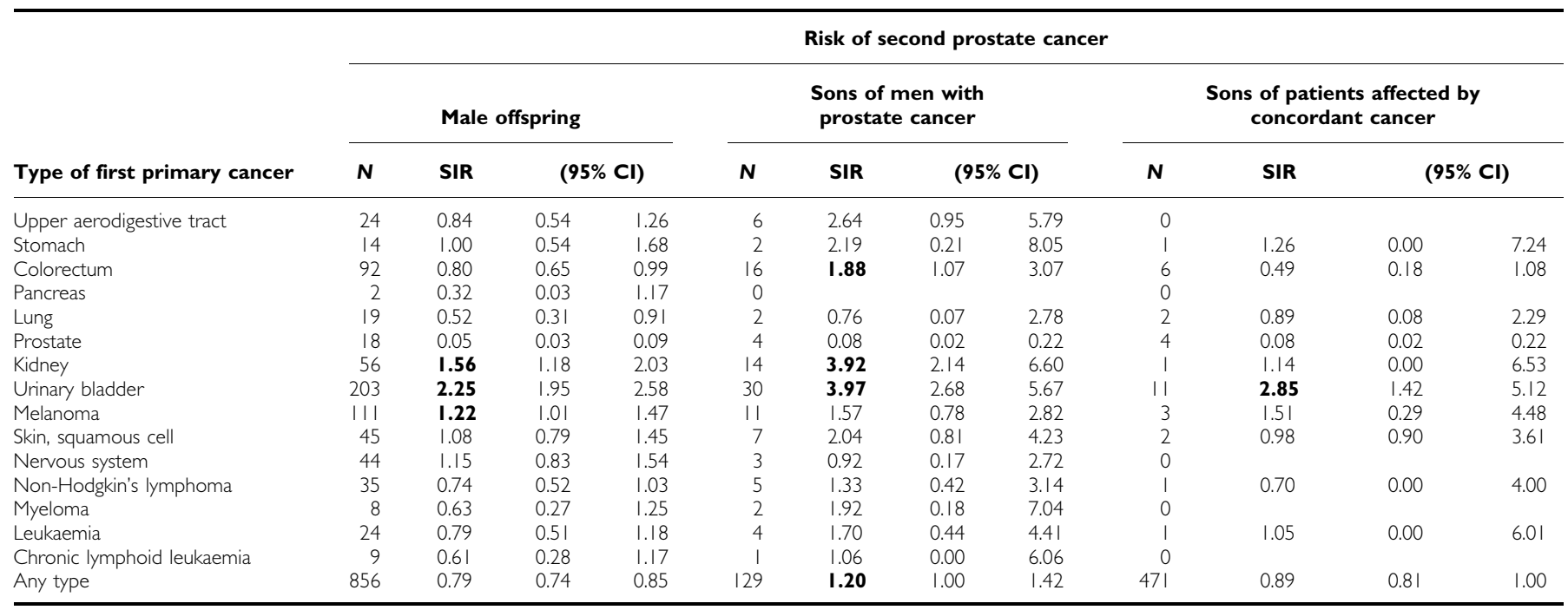

Abbreviations: $\mathrm{Cl}=$ confidence interval; $\mathrm{N}=$ number of individuals with second neoplasm; $\mathrm{SIR}=$ standardised incidence ratio. Bold refers to a significant risk increase with $5 \%$ statistical significance.

Table 3 Interaction between individual history of prostate cancer and family history of concordant cancer

\begin{tabular}{|c|c|c|c|c|c|c|c|c|c|c|c|c|c|c|c|c|c|c|c|c|}
\hline \multirow{3}{*}{$\begin{array}{l}\text { Type of second cancer } \\
\text { Colorectum }\end{array}$} & & & & & & & & & & & & & \multicolumn{8}{|c|}{ Type of interaction } \\
\hline & \multirow{5}{*}{76} & \multirow{4}{*}{$\begin{array}{l}\text { SIR } \\
1.23 \\
1.75 \\
1.83\end{array}$} & \multicolumn{2}{|c|}{$(95 \% \mathrm{Cl})$} & \multirow{2}{*}{$\frac{N}{1573}$} & \multirow{2}{*}{$\begin{array}{l}\text { SIR } \\
1.69\end{array}$} & \multicolumn{2}{|c|}{$(95 \% \mathrm{Cl})$} & \multirow{2}{*}{$\begin{array}{l}\mathbf{N} \\
11\end{array}$} & \multirow{2}{*}{$\begin{array}{l}\text { SIR } \\
2.26\end{array}$} & \multicolumn{2}{|c|}{$(95 \% \mathrm{Cl})$} & \multirow{2}{*}{$\frac{\mathbf{I C R}}{0.34}$} & \multicolumn{2}{|c|}{$(95 \% \mathrm{Cl})$} & \multirow{2}{*}{$\begin{array}{c}\boldsymbol{P} \text {-value } \\
0.68\end{array}$} & \multirow{2}{*}{$\begin{array}{l}\text { MII } \\
.09\end{array}$} & \multicolumn{2}{|c|}{$(95 \% \mathrm{Cl})$} & \multirow{2}{*}{$\frac{P \text {-value }}{0.59}$} \\
\hline & & & 0.99 & 1.51 & & & 1.61 & 1.78 & & & 1.12 & 4.06 & & -0.78 & 2.40 & & & 0.55 & 2.15 & \\
\hline Kidney & & & 1.20 & 2.46 & 119 & 2.19 & 1.82 & 2.62 & I & 2.72 & 0.00 & 15.6 & -0.27 & -3.22 & 104 & 0.48 & 0.70 & 0.02 & 28.8 & 0.43 \\
\hline Urinary bladder & & & 1.44 & 2.30 & 279 & 1.79 & 1.58 & 2.01 & 4 & 4.42 & 1.15 & 11.4 & 1.80 & -1.28 & 11.2 & 0.81 & 1.35 & 0.42 & 4.35 & 0.69 \\
\hline Skin, squamous cell & & 1.67 & 1.18 & 2.31 & 172 & 2.03 & 1.74 & 2.36 & 2 & 4.42 & 0.42 & 16.3 & 1.70 & -2.12 & 24.9 & 0.70 & 1.30 & 0.20 & 8.52 & 0.61 \\
\hline
\end{tabular}

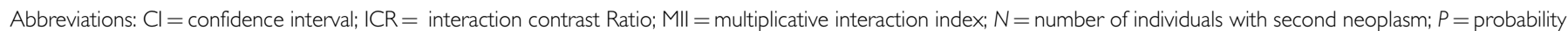
value for ICR larger than 0 and MII larger than I; SIR = standardised incidence ratio. Bold refers to a significant risk increase with $5 \%$ statistical significance.

registered at the time of birth of the child, thus allowing tracking of 'biological' parents in spite of divorce and remarriage. The study was limited because the maximum age in the offspring generation was 72 years, still below the highest risk for most cancer types, thus resulting in small numbers of familial cases. Moreover, no individual information on treatment or other potential cancer risk factors was available.

In this study, prostate cancer patients showed an increased risk of second tumours in the urinary bladder, kidney and skin (squamous cell). Patients affected by kidney and urinary bladder cancers, and by melanoma, showed an increased risk of subsequent prostate cancer. Novel data were related to the risk of second tumours in prostate cancer patients with a parental history of same-site tumours, which showed increased risks of colorectal $(\mathrm{SIR}=2.26)$ and urinary bladder $(\mathrm{SIR}=4.42)$ cancers and of chronic lymphoid leukaemia (SIR = 38.0).

Cancer treatment with radiation and chemotherapy has been related to the development of second malignancies. Since 1980, surgery, hormonal therapy and radiotherapy have been widely used to treat prostate cancer. Chemotherapy has not been applied. It has been shown that prostate cancer patients undergoing external beam radiation therapy have a higher risk of secondary cancer than do surgically treated patients and patients treated with other forms of radiation (Neugut et al, 1997; Brenner, 2000, 2006; Baxter et al, 2005; Brenner and Hall, 2006; Moon et al, 2006). The potential contribution of radiotherapy to the development of second tumours should be reflected in an increasing risk with increasing time after first diagnosis. However, additional analyses of the database revealed decreasing risks with lead time between the two diagnoses, which would limit the role of radiotherapy in the development of subsequent tumours (data not shown).

In this study, $15-20 \%$ of patients with second urinary bladder or prostate cancer had a concordant parental history. The familial risk of second bladder cancer after prostate cancer (4.42) was higher than the relative risk of bladder cancer after prostate cancer (1.83) and higher than the familial risk of bladder cancer (1.79). Theoretically, a family history of cancer may lead to a more intense screening of prostate cancer. Previous analyses from the database found no increased risk of prostate cancer shortly after a paternal prostate cancer diagnosis and a borderline risk $(P=0.07)$ after diagnosis of a brother (Bermejo and Hemminki, 2005). The absence of increased familial risks shortly after first diagnosis suggests a contribution of genetic factors rather than intensified medical attention.

On the basis of the independent effects of individual history of prostate cancer and family history of urinary bladder cancer and assuming an additive interaction model, the ICR would be $4.42-1.83-1.79+1=1.80$ (Table 3). Analogously, the results suggested a higher than multiplicative interaction between the individual history of prostate cancer and family history of bladder cancer, but the number of familial cases was small to rule out other interaction models. Hardly any susceptibility genes are known that would explain shared effects in prostate and bladder cancers. 
For second chronic lymphoid leukaemia after prostate cancer, it is difficult to explain the increased risks for a concordant parental cancer history, as no germline mutation has been identified so far (Sellick et al, 2005). Another new finding was the increased risks for skin squamous cell carcinoma after prostate cancer, when the offspring had a parental history of prostate cancer. Moreover, the MII suggested a higher than multiplicative interaction between the individual history of prostate cancer and family history of skin squamous cell carcinoma.

A family history of prostate cancer seems to have an important role in developing a second prostate cancer after any cancer other than prostate cancer, with an estimated SIR of 1.20. In addition to the candidate genes suggested earlier, a large number of low-risk variants have been associated with prostate cancer in genome-wide association studies (Dong, 2006; Eeles et al, 2008; Gudmundsson et al, 2008; Thomas et al, 2008). The interaction between family history and identified polymorphisms on prostate cancer risk has been investigated recently (Zheng et al, 2008). However, the present results indicate the association among discordant cancer sites, and the effects of most recently identified variants on colorectal, bladder and renal cancer have not been investigated yet.

On the basis of the Swedish Family-Cancer database, our results suggest that prostate cancer patients with a family history of cancer have an increased risk of concordant tumours in the urinary bladder. The increased risk in both directions - bladder after prostate and prostate after bladder tumours - points to the contribution of shared genetic and non-genetic risk factors. Although the number of parental cases was small, the data suggest that family history also seems to have an effect on other types of concordant cancers.

\section{ACKNOWLEDGEMENTS}

This study was supported by Deutsche Krebshilfe, the Swedish Cancer Society, the EU, LSHC-CT-2004-503465 and the Swedish Council for Working Life and Social Research. The Family-Cancer Database was created by linking registers maintained at Statistics Sweden and the Swedish Cancer Registry.

\section{REFERENCES}

Baxter NN, Tepper JE, Durham SB, Rothenberger DA, Virnig BA (2005) Increased risk of rectal cancer after prostate radiation: a populationbased study. Gastroenterology 128: 819-824

Bermejo JL, Hemminki K (2005) Familial risk of cancer shortly after diagnosis of the first familial tumor. $J$ Natl Cancer Inst 97: $1575-1579$

Bostrom PJ, Soloway MS (2007) Secondary cancer after radiotherapy for prostate cancer: should we be more aware of the risk? Eur Urol $\mathbf{5 2}$ 973-982

Bostrom PJ, Soloway MS, Manoharan M, Ayyathurai R, Samavedi S (2008) Bladder cancer after radiotherapy for prostate cancer: detailed analysis of pathological features and outcome after radical cystectomy. J Urol 179: 91 -95; discussion 95

Brenner DJ (2000) Toward optimal external-beam fractionation for prostate cancer. Int J Radiat Oncol Biol Phys 48: 315-316

Brenner DJ (2006) Induced second cancers after prostate-cancer radiotherapy: no cause for concern. Int J Radiation Oncology Biol Phys 65: 637-639

Brenner DJ, Hall EJ (2006) Re: Bladder cancer risk following primary and adjuvant external beam radiation for prostate cancer. J Urol 175: $788-789$

Centre for Epidemiology (2006) Cancer incidence in Sweden 2005, pp 7-10. The National Board of Health and Welfar: Stockholm

Chun TY (1997) Coincidence of bladder and prostate cancer. J Urol 157: 65-67

Diener-West M, Reynolds SM, Agugliaro DJ, Caldwell R, Cumming K, Earle JD, Hawkins BS, Hayman JA, Jaiyesimi I, Kirkwood JM, Koh WJ, Robertson DM, Shaw JM, Straatsma BR, Thoma J, Collaborative Ocular Melanoma Study Group (2005) Second primary cancers after enrollment in the COMS trials for treatment of choroidal melanoma: COMS Report No. 25. Arch Ophthalmol 123: 601-604

Dong C, Hemminki K (2001) Second primary neoplasms in 633964 cancer patients in Sweden, 1958-1996. Int J Cancer 93: 155-161

Dong JT (2006) Prevalent mutations in prostate cancer. J Cell Biochem 97: $433-447$

Eeles RA, Kote-Jarai Z, Giles GG, Olama AA, Guy M, Jugurnauth SK, Mulholland S, Leongamornlert DA, Edwards SM, Morrison J, Field HI, Southey MC, Severi G, Donovan JL, Hamdy FC, Dearnaley DP, Muir KR, Smith C, Bagnato M, Ardern-Jones AT, Hall AL, O’Brien LT, Gehr-Swain BN, Wilkinson RA, Cox A, Lewis S, Brown PM, Jhavar SG, Tymrakiewicz M, Lophatananon A, Bryant SL, UK Genetic Prostate Cancer Study Collaborators; British Association of Urological Surgeons' Section of Oncology; UK ProtecT Study Collaborators, Horwich A, Huddart RA, Khoo VS, Parker CC, Woodhouse CJ, Thompson A, Christmas T, Ogden C, Fisher C, Jamieson C, Cooper CS, English DR, Hopper JL, Neal DE, Easton DF (2008) Multiple newly identified loci associated with prostate cancer susceptibility. Nat Genet 40: 316-321
Gudmundsson J, Sulem P, Rafnar T, Bergthorsson JT, Manolescu A, Gudbjartsson D, Agnarsson BA, Sigurdsson A, Benediktsdottir KR, Blondal T, Jakobsdottir M, Stacey SN, Kostic J, Kristinsson KT, Birgisdottir B, Ghosh S, Magnusdottir DN, Thorlacius S, Thorleifsson G, Zheng SL, Sun J, Chang BL, Elmore JB, Breyer JP, McReynolds KM, Bradley KM, Yaspan BL, Wiklund F, Stattin P, Lindström S, Adami HO, McDonnell SK, Schaid DJ, Cunningham JM, Wang L, Cerhan JR, St Sauver JL, Isaacs SD, Wiley KE, Partin AW, Walsh PC, Polo S, Ruiz-Echarri M, Navarrete S, Fuertes F, Saez B, Godino J, Weijerman PC, Swinkels DW, Aben KK, Witjes JA, Suarez BK, Helfand BT, Frigge ML, Kristjansson $\mathrm{K}$, Ober $\mathrm{C}$, Jonsson E, Einarsson GV, Xu J, Gronberg $\mathrm{H}$, Smith JR, Thibodeau SN, Isaacs WB, Catalona WJ, Mayordomo JI, Kiemeney LA, Barkardottir RB, Gulcher JR, Thorsteinsdottir U, Kong A, Stefansson K (2008) Common sequence variants on $2 \mathrm{p} 15$ and Xp11.22 confer susceptibility to prostate cancer. Nat Genet 40: $281-283$

Hemminki K, Boffetta P (2004) Multiple primary cancers as clues of environmental and heritable courses of cancer and of mechanisms of carcinogenesis. IARC Sci Publ 57: 289-297

Hemminki K, Granstrom C, Sundquist J, Lorenzo Bermejo J (2006) The nation-wide Swedish Family-Cancer Database used to assess familial risks of prostate cancer during rapidly increasing incidence. Heredit Cancer in Clin Pract 4: 186-192

Hemminki K, Li X, Plna K, Granström C, Vaittinen P (2001) The nationwide Swedish family-cancer database-updated structure and familial rates. Acta Oncol 40: $772-777$

Kellen E, Zeegers MP, Dirx M, Houterman S, Droste J, Lawrence G, Truyers C, Bruckers L, Molenberghs G, Joniau S, Buntinx F (2007) Occurrence of both bladder and prostate cancer in five cancer registries in Belgium, The Netherlands and the United Kingdom. Eur J Cancer 43: $1694-1700$

Kendal WS, Eapen L, Macrae R, Malone S, Nicholas G (2006) Prostatic irradiation is not associated with any measurable increase in the risk of subsequent rectal cancer. Int J Radiat Oncol Biol Phys 65: $661-668$

Kouriefs C, Fazili T, Masood S, Naseem MS, Mufti GR (2005) Incidentally detected prostate cancer in cystoprostatectomy specimens. Urol Int 75 $213-216$

Liauw SL, Sylvester JE, Morris CG, Blasko JC, Grimm PD (2006) Second malignancies after prostate brachytherapy: incidence of bladder and colorectal cancers in patients with 15 years of potential follow-up. Int $J$ Radiat Oncol Biol Phys 66: 669-673

Moon K, Stukenborg GJ, Keim J, Theodorescu D (2006) Cancer incidence after localized therapy for prostate cancer. Cancer 107: 991-998

Neugut AI, Ahsan H, Robinson E, Ennis RD (1997) Bladder carcinoma and other second malignancies after radiotherapy for prostate carcinoma. Cancer 79: 1600 - 1604 
Neuzillet Y, Lechevallier E, Coulange C (2007) Renal cancer and second cancer: critical review of the literature. Prog Urol 17: 35-40

Sellick GS, Coleman RJ, Talaban RV, Fleischmann C, Rudd MF, Allinson R, Catovsky D, Houlston RS (2005) Germline mutations in Dok1 do not predispose to chronic lymphocytic leukaemia. Leuk Res 29: 59-61

Singh A, Kinoshita Y, Rovito Jr PM, Landas S, Silberstein J, Nsouli I, Wang CY, Haas GP (2008) Higher than expected association of clinical prostate and bladder cancers. J Urol 179: S2 - S5

Sørensen HT, Pedersen L, Mellemkjaer L, Johnsen SP, Skriver MV, Olsen JH, Baron JA (2005) The risk of a second cancer after hospitalisation for venous thromboembolism. Br J Cancer 93: 838-884

Subramanian S, Goldstein DP, Parlea L, Thabane L, Ezzat S, Ibrahim-Zada I, Straus S, Brierley JD, Tsang RW, Gafni A, Rotstein L, Sawka AM (2007) Second primary malignancy risk in thyroid cancer survivors: a systematic review and meta-analysis. Thyroid 17: 1277-1288

Thomas G, Jacobs KB, Yeager M, Kraft P, Wacholder S, Orr N, Yu K, Chatterjee N, Welch R, Hutchinson A, Crenshaw A, Cancel-Tassin G, Staats BJ, Wang Z, Gonzalez-Bosquet J, Fang J, Deng X, Berndt SI, Calle EE, Feigelson HS, Thun MJ, Rodriguez C, Albanes D, Virtamo J,
Weinstein S, Schumacher FR, Giovannucci E, Willett WC, Cussenot O, Valeri A, Andriole GL, Crawford ED, Tucker M, Gerhard DS, Fraumeni Jr JF, Hoover R, Hayes RB, Hunter DJ, Chanock SJ (2008) Multiple loci identified in a genome-wide association study of prostate cancer. Nat Genet 40: $310-315$

Travis LB (2006) The epidemiology of second primary cancers. Cancer Epidemiol Biomarkers Prev 15: 2020-2026

Travis LB, Rabkin CS, Brown LM, Allan JM, Alter BP, Ambrosone CB, Begg CB, Caporaso N, Chanock S, DeMichele A, Figg WD, Gospodarowicz MK, Hall EJ, Hisada M, Inskip P, Kleinerman R, Little JB, Malkin D, Ng AK, Offit K, Pui CH, Robison LL, Rothman N, Shields PG, Strong L, Taniguchi T, Tucker MA, Greene MH (2006) Cancer survivorship genetic susceptibility and second primary cancers: research strategies and recommendations. J Natl Cancer Inst 98: 15-25

Zheng SL, Sun J, Wiklund F, Smith S, Stattin P, Li G, Adami HO, Hsu FC, Zhu Y, Bälter K, Kader AK, Turner AR, Liu W, Bleecker ER, Meyers DA, Duggan D, Carpten JD, Chang BL, Isaacs WB, Xu J, Grönberg H (2008) Cumulative association of five genetic variants with prostate cancer. N Engl J Med 358: 910 - 919 